\title{
QUALITY EVALUATION OF CHEESE PREPARED BY PLANT COAGULANTS: CARICA PAPAYA AND MORINGA OLEIFERA LEAVES
}

\author{
Waheed M. ${ }^{1}$, Hussain M.B. ${ }^{1}$, Majeed M. ${ }^{2}$, Rehman T.U. ${ }^{1}$, Khan M.U. ${ }^{3 *}$, \\ Shariati M.A. ${ }^{4}$, Plygun S.A. ${ }^{4}$, Glinushkin A.P. ${ }^{4}$ \\ ${ }^{1}$ Institute of Home and Food Sciences, Government College University, Pakistan \\ ${ }^{2}$ National Institute of Food Science and Technology, University of Agriculture, Pakistan \\ ${ }^{3}$ Department of Energy Systems Engineering, University of Agriculture, Pakistan \\ ${ }^{4}$ All Russian Research Institute of Phytopathology, Russia \\ ${ }^{*}$ E-mail: engineer usman khan@yahoo.com
}

\begin{abstract}
Owing to the prevalence of numerous human ailments in current epoch, use of natural food in manufacturing of variant processed stuffs has captured the attention of researchers, quite considerably as they comprise of beneficial components. In this regard, utilization of plant derived enzymes is making its mark, attributable to their easy availability and resistivity to survive severe processing conditions i.e. temperature and $\mathrm{pH}$. The purpose of the study was to extract protease from Carica papaya and Moringa oleifera leaves and cheese was manufactured by using different levels of extract concentrations as rennet substitute. Enzyme extract was subjected to protein content, milk clotting and proteolytic activity for the pursuit of its effectiveness in cheese preparation. Different cheese treatments were analyzed for their physicochemical, functional and sensory properties. Fat, moisture and protein contents showed highly significant $(p<0.01)$ results in cheese. Whereas enzyme extract induced non-significant $(p>0.05)$ effect on ash, acidity and $\mathrm{pH}$ values of cheese. Results showed that cheese manufactured by using papaya leaf extract i.e. $T_{3}$ and $T_{4}$ exhibited good chemical and functional attributes comparable to control i.e. $\mathrm{T}_{0}$ (use of rennet). In conclusion, papaya protease proved to be a good plant coagulant with gigantic potential to replace rennet.
\end{abstract}

\section{KEY WORDS}

Carica papaya, Moringa oleifera, protease, milk clotting, cheese.

Amplifying utilization of plant-derived foodstuffs has been documented over the last epochs owing to the presence of beneficial constituents like phytochemicals, hormones, vitamins, enzymes, antioxidants and other nutritional components (Atanasov et al., 2015).

Use of plant derived proteases have been reported in cheese making because of their milk clotting activity. In West African, Southern European and Mediterranean countries, plant coagulant used for cheese making. In 2014, global industrial enzyme market estimated around $\$ 4.2$ billion and likely to develop at a compound annual growth rate (CAGR) of almost $7 \%$ from 2015 to 2020 to reach at $\$ 6.2$ billion and proteases are related to the biggest section of this market (Singh et al., 2016).

The papaya (Carica papaya Linn.) is an evergreen plant found in tropical regions, originated from Central America and Mexico (Yogiraj et al., 2014). The chemical composition of papaya discovered the presence of sodium along with potassium $(223 \mathrm{mg} / 100 \mathrm{~g}$ of fresh fruit), manganese, magnesium, iron, copper, calcium, phosphorus and zinc in significant amounts. Papaya sustains a key position among the fruits for iron, potassium, calcium, fiber, thiamine, folate, riboflavin, niacin, vitamin A, B1, B2 and C contents (Saeed et al., 2014). Papaya proteases like papain are currently utilized for cheese manufacturing, beverage and brewing industries. Hence, the cheese obtained from papaya leaves having coagulation property is due to the proteolytic activity of papain (Li et al., 2013).

Moringa (Moringa oleifera Lam.) is a versatile and extraordinarily nourishing vegetable tree having a variety of potential usages. It is considered as most beneficial tree in the world and every part of moringa tree can be utilized for food or has some other advantageous 
property (Mishra et al., 2012). Moringa leaves have been testified to be a rich source of calcium, potassium, $\beta$-carotene, vitamin $C$, protein and thus boost the shelf-life of fat containing foods due to antioxidant compounds for example phenolics, ascorbic acid, carotenoids and flavonoids (Dalei et al., 2016; Mbikay, 2012). Milk clotting activity from moringa preparations has been related to serine and aspartic proteases for cheese preparation.

Production of cheese increased by a factor of around 3.5 since 1961 but the supply of rennet decreased because of the limited accessibility of ruminant stomachs (Shah et al., 2014). Various aspects such as ban on recombinant calf rennet (in France, Germany and The Netherlands), religious concerns (e.g. Islam and Judaism), high price of rennet and diet (vegetarianism) have stimulated the pursuit for alternative milk-clotting sources (Puglisi et al., 2014). Therefore, the thrust of this study is to evaluate the efficacy of different concentrations of papaya and moringa protease for the manufacturing of cheese, as plant protease shows optimum activity and stability in milk clotting.

\section{MATERIALS AND METHODS OF RESEARCH}

Procurement of raw material. Milk was procured from Dairy Farm, University of Agriculture, Faisalabad. Papaya leaves for enzyme extraction were procured from Botanical Garden and moringa from Crop Physiology Department, University of Agriculture, Faisalabad. Enzyme extraction and further analysis were carried out in Biotech Laboratory and Dairy Technology Laboratory, National Institute of Food Science and Technology.

Preparation of sample. The leaves samples of $C$. papaya and M. oleifera were washed carefully with tap water to remove dust and insects. The washed leaves samples were dried under shade at room temperature for 3 days. After completing dry, about $500 \mathrm{~g}$ of leaves of C. papaya and M. oleifera were ground using kitchen grinder and passed through 25 mesh sieves and stored at room temperature until further use.

Phase 1: Enzyme extraction and analysis. Protease enzyme was extracted from leaves by following the method of Dahot et al. (1990). In which $20 \mathrm{~g}$ of leaves sample was extracted with $100 \mathrm{~mL}$ ice-cold acetone in presence of some amount of glass powder using a pestle mortar. The slurry was filtered through Whatman No. 1 filter paper. The residues were spread on filter paper and allowed to dry at $20^{\circ} \mathrm{C}$. This acetone dried powder was grinded in pestle mortar with $25 \mathrm{~mL}$ ice cold $0.2 \mathrm{M}$ citrate-phosphate buffer $(\mathrm{pH} \mathrm{7.0)}$ and the slurry was centrifuged at $6000 \mathrm{rpm}$ for 10 minutes. The supernatant containing enzyme was transferred to $100 \mathrm{~mL}$ volumetric flask and this procedure was repeated twice. The total volume was made up with ice-cold citrate-phosphate buffer. This freshly prepared extract solution was used for estimating protein contents, milk clotting and proteolytic activity.

Biuret method was used for protein analysis of enzyme extract as it was described by Gornall et al. (1949). All the tests were carried out in triplicates. For standard curve, take 5 test tubes label them through 1-5. Add $0.1 \%$ solution of standard BSA (Bovine serum albumin), increasing the volume from $0.1-0.5 \%$ in test tube 1-5, respectively. Add distilled water to make final volume upto $5 \mathrm{~mL}$. Then add $1 \mathrm{~mL}$ of biuret reagent to all the 5 test tubes. Test solution was prepared by taking 2 test tubes, mark as blank and experimental and add $1 \mathrm{~mL}$ biuret reagent in both test tubes. Add $1 \mathrm{~mL}$ of enzyme extract experimental tube and $1 \mathrm{~mL}$ water to blank one. Incubate standard, blank and experimental tubes in water bath at $37^{\circ} \mathrm{C}$, for 15 minutes. Absorbance was recorded against blank at $540 \mathrm{~nm}$ by using spectrophotometer.

Protease assay of papaya and moringa leaves extract was carried out by the method of Pyrc et al. (2011), in which enzyme activity was determined by the casein digestion assay. Since substrate grade caseins can vary from lot to lot and according to the manner produced, the standardization of casein digestion assays had been difficult to achieve. The use of a reference enzyme preparation was suggested.

Milk clotting activity of leaves extract was assessed by the method of Saliha et al. (2011). The standard substrate, $10 \%(\mathrm{w} / \mathrm{v})$ of low heat milk powder in $\mathrm{CaCl}_{2}(0.01 \mathrm{M})$ solution was prepared, and the $\mathrm{pH}$ was adjusted to 6.5 with $0.1 \mathrm{~N} \mathrm{NaOH}$. The protease enzyme 
extract (PEE) $1 \mathrm{~mL} / 10 \mathrm{~mL}$ of standard substrate was added, mixed manually and incubated in a water bath at $30^{\circ} \mathrm{C}$. After complete mixing, the "zero" clotting time started. It was measured in units $/ \mathrm{mL}$.

Phase 2: Product development and analysis. Cheese was prepared by using different levels of enzyme extracts obtained from papaya and moringa leaves as rennet substitute. Boshra and Tajul, (2013) reported that protease / papain has milk clotting ability like rennet in cheese manufacturing.

Moisture content of all cheese samples prepared by using papaya extract as coagulant was determined by oven drying method as given in AOAC, 926.08 (1990). $3 \mathrm{~g}$ of grated and shredded cheese sample were weighed in a round, flat bottom metal dish and placed in oven at $100^{\circ} \mathrm{C}$ and dried to constant weight, cooled and weighed. Loss in weight was expressed as moisture.

The $\mathrm{pH}$ of all cheese samples was measured using $\mathrm{pH}$ meter (Model No.wtw82362 Wellheim) by following the method of Ong et al. (2007). Before measuring $\mathrm{pH}, \mathrm{pH}$ meter was calibrated using buffers of $\mathrm{pH} 4$ and 7 . After calibration the cheese sample was mixed in distilled water in the beaker and then by inserting the rod of $\mathrm{pH}$ meter in the beaker, $\mathrm{pH}$ of the cheese sample was recorded.

Acidity in cheese was determined by titration method as given in AOAC, 920.124 (1990). $1 \mathrm{~g}$ cheese sample was taken in beaker. $10 \mathrm{~mL}$ of warm water was added in the beaker and vigorously shaked. Filter the contents and filtrate was titrated against $0.1 \mathrm{~N}$ $\mathrm{NaOH}$ using phenolphthalein as indicator.

Protein in cheese was analyzed according to the method of IDF, (2001).

Fat contents of the cheese samples was measured by Gerber method as described by Marshal, (1992).10 mL sulphuric acid was measured and taken in the cheese butyrometer than $3 \mathrm{~g}$ of cheese sample measured in the butter paper was inserted into the butyrometer containing sulphuric acid. At the end $3 \mathrm{~mL}$ isoamyl alcohol was added. $5 \mathrm{~mL}$ distilled water was also added. The butyrometer was properly stoppered. The mixture in the butyrometer was mixed gently and kept for centrifugation at $1100 \mathrm{rpm}$ for 5 minutes. The fat level of the sample was noted from the graduated scale.

Ash content in cheese was determined by igniting the cheese sample by following Method No. 935.42 of AOAC (1990). Grated cheese sample $(5 \mathrm{~g})$ was weighed in a china dish and first ignited on flame and then in muffle furnace at $550^{\circ} \mathrm{C}$ until the constant weight of white ash is obtained.

The consumer acceptance of different samples for various attributes including color, flavor, taste, texture and overall acceptability was carried out by trained taste panel using hedonic score system as described by Meilgaard et al. (2007).

All the analyses were performed in triplicate. The results were subjected to statistical analysis (CRD) in order to check level of significance as described by Steel et al. (1997). Means of different treatments were compared by using LSD-Test to identify significance or non-significance among treatment means.

\section{RESULTS AND DISCUSSION}

Extract Analysis. The results of our present study showed that papaya and moringa protease used for coagulation or clotting of milk for cheese preparation. Protein contents, milk clotting and proteolytic activity of extracted protease presented in Table 1.

Table 1 - Protein contents, proteolytic activity and milk clotting activity of Moringa oleifera and Carica papaya

\begin{tabular}{|c|c|c|c|}
\hline Plant Parts & Protein Contents $(\mathrm{mg} / \mathrm{mL})$ & Proteolytic Activity $(\mathrm{U} / \mathrm{mL})$ & Milk Clotting Activity $(\mathrm{U} / \mathrm{mL})$ \\
\hline Moringa oleifera Leaves & 1.1 & 5 & 120 \\
\hline Carica papaya Leaves & 1.2 & 7 & 170 \\
\hline
\end{tabular}




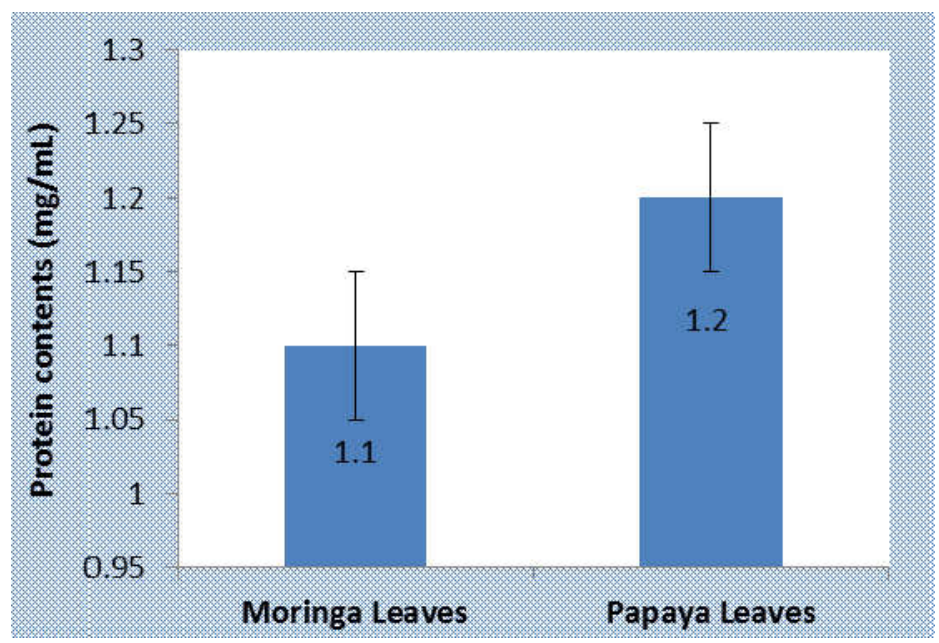

Figure 1 - Protein contents determination of leaves extract

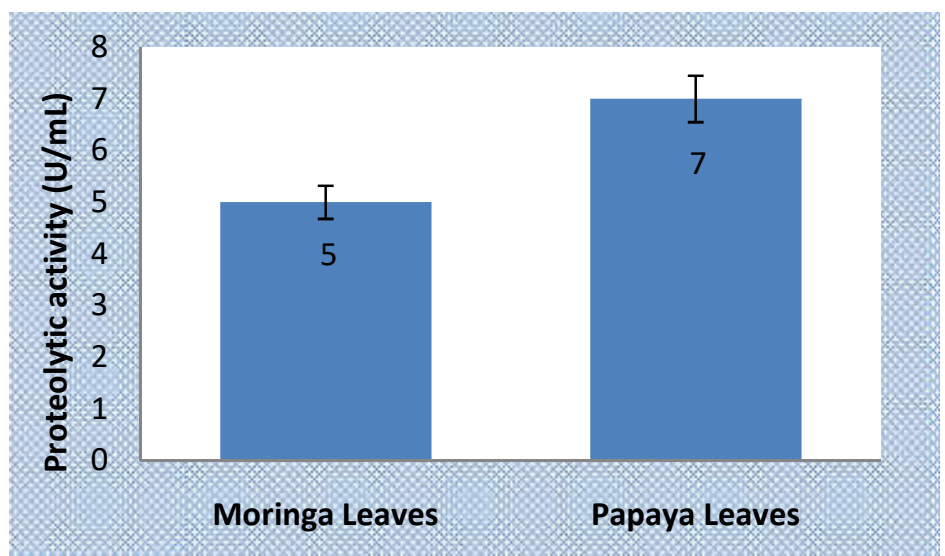

Figure 2 - Proteolytic activity measurement of leaves extract

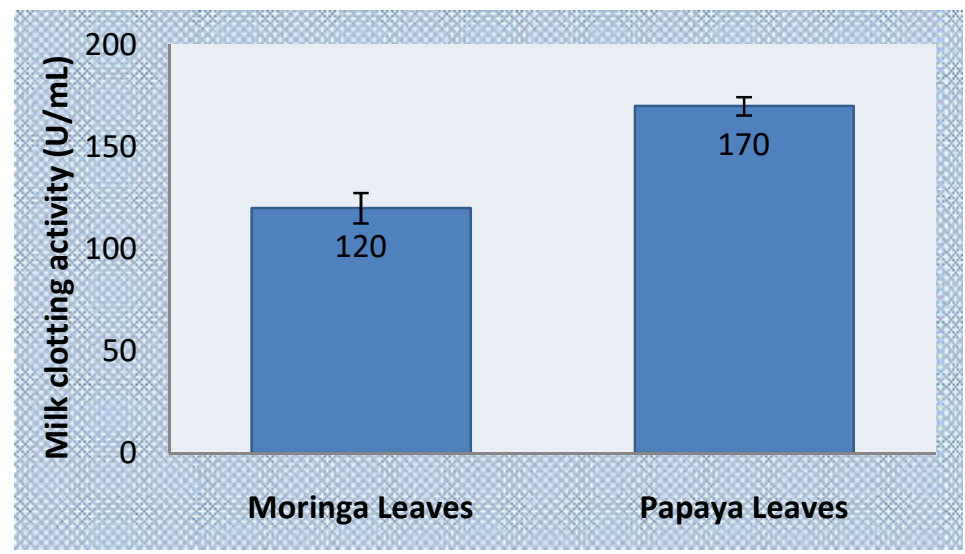

Figure 3 - Milk clotting activity of leaves extract

Moringa leaf extract showed less difference in protein contents i.e. $1.1 \mathrm{mg} / \mathrm{mL}$ as compared to papaya i.e. $1.2 \mathrm{mg} / \mathrm{mL}$. Similarly proteolytic and milk clotting activity was also more in case of papaya extract i.e. ( 7 Units $/ \mathrm{mL})$ and $(170$ Units $/ \mathrm{mL})$, respectively. Results of these parameters were also represented graphically as in Figures 1,2 and 3. The results obtained from this study were quite similar with the results of (Agrahari and Sharma, 2014). They also reported that senesced leaves of Carica papaya are associated with several fold increase in activity of protease and milk clotting.

Physicochemical Analysis of Milk. Cheese manufacturing commences with the selection of high physicochemical properties milk. Samples of milk were subjected to 
compositional analyses to determine the suitability of milk for the preparation of cheese. Table 2 shows the complete physicochemical composition of milk. Results depicted that proteins $(3.85 \%)$ and fat $(3.5 \%)$ were relatively higher than cow milk. Lactose and moisture content were 4.86 and $87.09 \%$, respectively. Acidity and $\mathrm{pH}$ value of milk were $0.11 \%$ and 6.8 , respectively. Ash contents were $0.46 \%$ as well as total solids having compositional value i.e. $13.61 \%$. The buffalo milk has higher content of total solids, lactose, fat and protein than cow milk, which makes it suitable for manufacturing of milk products, especially cheese production (Rafiq et al., 2016; Murtaza et al., 2014). Results of these current analyses were agreed with the findings of protein, fat, acidity and $\mathrm{pH}$ of buffalo milk by Ahmad et al. (2013).

Table 2 - Physicochemical composition of cheese milk

\begin{tabular}{|c|c|}
\hline Parameter & Milk composition \pm S.D \\
\hline Moisture & $87.09 \% \pm 0.03$ \\
\hline $\mathrm{pH}$ & $6.80 \pm 0.03$ \\
\hline Acidity & $0.11 \% \pm 0.01$ \\
\hline Fat & $3.5 \% \pm 0.02$ \\
\hline Protein & $3.85 \% \pm 0.01$ \\
\hline Ash & $0.46 \% \pm 0.02$ \\
\hline Lactose & $4.86 \% \pm 0.03$ \\
\hline Total Solids & $13.61 \% \pm 0.52$ \\
\hline
\end{tabular}

Physicochemical properties of cheese. The effect of using plant protease extract in cheese physicochemical properties is mentioned in Table 3 . It shows that there is no significant $(\mathrm{P}>0.05)$ difference in acidity of cheese prepared by using papaya and moringa leaves extract (5 and 10\%). Acidity percentage in different treatments was in the range of $0.76 \%$ to $0.83 \%$. Maximum value observed in $\mathrm{T}_{3}$ i.e. $0.81 \%$ followed $\mathrm{T}_{1}$ i.e. $0.77 \%$. Minimum acidity (\%) was found in $\mathrm{T}_{2}$ and $\mathrm{T}_{4}$ i.e. $0.76 \%$. Results are nearly in agreement with the findings of (Abou-zeid, 2015). They reported that there was no significant difference detected for most of physicochemical components $(\mathrm{pH}$, acidity and fat) of Ras cheese manufactured by plant enzymes.

The ash content in cheese represents the inorganic matters remaining after the organic matters have been burnt. Mean value of ash content is given in Table 3 . There was no significant $(p>0.05)$ difference between all the treatments. Ash contents remain virtually constant with increase in concentration of moringa and papaya leaf extract. Results of present study are supported by Harun et al. (2015). They reported that ash \%age was slightly higher but statistically insignificant in cheese made with Solanum dubium coat extract.

Fat contents in different treatments were in the range of 18.20 to $18.63 \%$ in Table 3. There was no significant difference in fat content between $T_{0}$ and $T_{3}$ but these have highly significant $(p<0.01)$ difference with other treatments. Results of present study revealed that fat content of cheese increases with increase in papaya extract and due to raw milk fat. Papaya leaves have numberless of nutritional ingredients and fatty acid composition that cause increase in total fat of final cheese. These findings are in accordance with Arvind et al. (2013). Mahajan and Chaudhari, (2014) found highest fat content in cheese prepared by latex of four plants i.e. E. tirucalli $(22.6 \%)$, E. nerifolia $(22.1 \%)$, P. tithymaloides $(21.5 \%)$ and E. nivulia (21.2\%).

Table 3 - Mean \pm S.D values for Acidity, Ash, Fat, Moisture, Protein and $\mathrm{pH}$

\begin{tabular}{|c|c|c|c|c|c|c|}
\hline Treatment & Acidity & Ash & Fat & Moisture & Protein & $\mathrm{pH}$ \\
\hline $\mathrm{T}_{0}$ & $0.83 \pm 0.04$ & $3.20 \pm 0.02$ & $18.61 \pm 0.06$ & $51.52 \pm 0.16$ & $23.81 \pm 0.12$ & $5.05 \pm 0.06$ \\
\hline $\mathrm{T}_{1}$ & $0.77 \pm 0.8$ & $3.25 \pm 0.01$ & $18.24 \pm 0.07$ & $49.70 \pm 0.14$ & $17.27 \pm 0.10$ & $5.12 \pm 0.02$ \\
\hline $\mathrm{T}_{2}$ & $0.76 \pm 0.04$ & $3.23 \pm 0.04$ & $18.20 \pm 0.09$ & $49.45 \pm 0.12$ & $19.71 \pm 0.19$ & $5.13 \pm 0.03$ \\
\hline $\mathrm{T}_{3}$ & $0.81 \pm 0.02$ & $3.26 \pm 0.01$ & $18.60 \pm 0.18$ & $51.13 \pm 0.13$ & $18.52 \pm 0.18$ & $5.07 \pm 0.05$ \\
\hline $\mathrm{T}_{4}$ & $0.76 \pm 0.06$ & $3.22 \pm 0.04$ & $18.63 \pm 0.11$ & $51.17 \pm 0.12$ & $20.90 \pm 0.12$ & $5.12 \pm 0.08$ \\
\hline
\end{tabular}


Mean values of moisture content are presented in Table 3 . Moisture content in different treatments was in the range of $49.45 \%$ to $51.52 \%$. There was highly significant $(p<0.01)$ difference in moisture content between all the treatments because of the optimum moisture content in papaya and moringa leaves i.e. $81 \%$ and $71.34 \%$ according to Vyas et al. (2014) and Asante et al. (2014) respectively.

Different concentrations of leaves extract showed highly significant $(p<0.01)$ effect on protein contents of cheese. This is due to the exceptional nutritional worth of papaya and moringa as studied by Silva et al. (2016) and Belewu et al. (2014) respectively.

Table 3 shows a little bit difference $(p>0.05)$ in $\mathrm{pH}$ of cheese. This might be due to higher acidity in raw milk. Results of Rafiq et al. (2016) showed significant increase $(p<0.05)$ in $\mathrm{pH}$ of buffalo milk cheddar cheese (BCC) over the ripening period of 180 days.

Sensory properties of cheese. Cheese color is an important criterion of acceptance by cheese consumers. Creamy yellow color in cheese is accepted by the consumer. Color of cheese prepared using papaya and moringa leaves extract effect significantly $(p \leq 0.05)$. In the present study, statistical results regarding color of cheese showed in Table 4. Score of color in different treatments was in the range of 5.33 to 7.66 . Maximum color was 7.66 in $\mathrm{T}_{4}$ followed $T_{0}$ i.e. 7.33 . Minimum values were observed in $T_{1}$ i.e. 5.33 in which $5 \%$ moringa leaf protease extract used. Color score increases with increase in concentration of leaves extract. This may be attributed to the fact that the concentration of colored plant extract added to the cheese milk was much higher than that of the calf rennet (Agboola et al., 2009).

Texture particularly in cheese, is one of the most important attribute that helps to verify the identity of a product. As mentioned in Table 4, cheese texture showed highly significant $(p<0.01)$ results as manufactured by plant protease extract. Score of texture in different treatments was in the range of 5.00 to 7.33 in which $5 \%$ moringa and $10 \%$ papaya leaves extract used respectively. Cheese made with plant protease extract has a more uniform and softer body texture than animal source. Proteolytic activity of ginger contributed to textural softening during ripening of Iranian ultra-filtrate white cheese as described by Fathollahi et al. (2010).

Table 4 - Mean \pm S.D value for Color, Flavor, Texture, Taste and Overall acceptability

\begin{tabular}{|c|c|c|c|c|c|}
\hline Treatment & Color & Texture & Flavor & Taste & Overall acceptability \\
\hline $\mathrm{T}_{0}$ & $7.33 \pm 0.51$ & $6.66 \pm 0.57$ & $7.00 \pm 0.58$ & $7.00 \pm 0.60$ & $7.66 \pm 0.57$ \\
\hline $\mathrm{T}_{1}$ & $5.33 \pm 0.57$ & $5.00 \pm 0.55$ & $6.67 \pm 0.57$ & $6.00 \pm 0.57$ & $5.66 \pm 0.51$ \\
\hline $\mathrm{T}_{2}$ & $6.66 \pm 0.53$ & $7.00 \pm 0.53$ & $7.33 \pm 0.51$ & $6.66 \pm 0.56$ & $6.66 \pm 0.53$ \\
\hline $\mathrm{T}_{3}$ & $6.33 \pm 0.51$ & $6.66 \pm 0.57$ & $7.00 \pm 0.58$ & $7.00 \pm 0.60$ & $6.66 \pm 0.53$ \\
\hline $\mathrm{T}_{4}$ & $7.66 \pm 0.53$ & $7.33 \pm 0.61$ & $6.66 \pm 0.53$ & $7.66 \pm 0.51$ & $8.00 \pm 0.61$ \\
\hline
\end{tabular}

Statistical results regarding flavor of cheese prepared by moringa and papaya leaves protease did not differ significantly $(p>0.05)$. Maximum flavor contents were found in $T_{2}$ i.e. 7.33 and minimum were observed in $\mathrm{T}_{4}$ i.e. 6.66 in $10 \%$ moringa and $10 \%$ papaya leaves extract respectively. This study is compatible with the results of Tajeda et al. (2008). They reported that there is no change in flavor when plant protease was used as a rennet substitute.

The mean value for taste is given in Table 4. Value of taste in different treatments was in the range of 6.00 to 7.66 . With increase in concentration of plant protease extract in cheese, value of taste did not change significantly. There was no bitterness noted by any member of the sensory panel.

Overall acceptability increases with increase in concentration of plant protease extract. $\mathrm{T}_{4}$ is best because $10 \%$ papaya leaves extract was used and it has highest overall acceptance score i.e. 8.00. No off flavor and taste bitterness was reported in $T_{4}$ but overall it showed highly significant $(p<0.01)$ difference as compared to other treatments. These results are in accordance with the findings of El-Aziz et al. (2012). They indicated that fortification of buffalo milk with ginger extract resulted in more softness and smoothness during storage of cheese but high score for overall acceptability of cheese. 


\section{CONCLUSION}

Based on the results of this experiment, the inclusion of Carica papaya and Moringa oleifera protease in cheese preparation improves its chemical composition. Cheese with papaya protease showed the best performance as compared to moringa in terms of milk clotting, proteolytic activity and its physicochemical composition. It could therefore recommended that dairy industries must utilize plant sources as substitute of calf rennet because of easy availability with simple purification process of protease and provide great possibility for large scale preparation.

\section{REFERENCES}

1. Abou-zeid, N.A. 2015. The use of plant enzymes for ripening acceleration of Ras cheese. IIOAB. J. 6 (2): 15-21.

2. Agboola, S.O., H.H. Chan, J. Zhao and A. Rehman. 2009. Can the use of Australian cardoon (Cynara cardunculus $L$ ) coagulant overcome the quality problems associated with cheese made from ultrafiltered milk. Food Sci. Technol. 42:1352-1359.

3. Agrahari, S and N. Sharma. 2014. Extraction and characterization of protease from senesced

4. leaves of Papaya (Carica Papaya) and its application. Int. J. Gen. Eng. Biotech. 5(1): 2934.

5. Ahmad, S., F. M. Anjum, N. Huma, A. Sameen and T. Zahoor. 2013. Composition and physico-chemical characteristics of buffalo milk with particular emphasis on lipids, proteins, minerals, enzymes and vitamins. J. Anim. PI. Sci. 23: 62-74.

6. AOAC Association of Official Analytical Chemists. 1990. Official Methods of Analysis of AOAC. $15^{\text {th }}$ Ed. AOAC Press, Arlington, VA, USA.

7. Arvind G, Bhowmik D, Duraivel S, Harish G. 2013.Traditional and medicinal uses of Carica papaya. J. Med. Car. Pap. 1(1): 2320-3862.

8. Asante, W.J., I.L. Nasare, D. Tom-Dery, K. Ochire-Boadu and K. B. Kentil. 2014. Nutrient composition of Moringa oleifera leaves from two agro ecological zones in Ghana. Afr. J. Plant Sci. 8(1): 65-71.

9. Atanasov, A.G., B. Waltenberger, E.M. Pferschy-Wenzig, T. Linder, C. Wawrosch, P. Uhrin, V. Temml, L. Wang, S. Schwaiger, E.H. Heiss, J.M. Rollinger, D. Schuster, J. M. Breuss, V. Bochkov, M. D. Mihovilovic, B. Kopp, R. Bauer, V. M. Dirsch and H. Stuppner. 2015. Discovery and resupply of pharmacologically active plant-derived natural products: A review. Biotechnol. Adv. 33(8): 1582-1614.

10. Belewu, M. A., M. A. Ahmed, A. H. A. Badmos, T.O. Esan, K.O. Abdulsalam, M. B. Odebisi and A. K. Arise1. 2014. Effect of different levels of Moringa oleifera oil on performance characteristics of pregnant goat. Niger. J. Agri. Food Env. 10(2): 29-33.

11. Boshra, V and A.Y. Tajul. 2013. Papaya- An innovative raw material for food and pharmaceutical processing industry. J. Health Env. 4(1): 68-73.

12. Dahot, M.U., M.Y. Khan and A.N. Memon. 1990. Screening of some Pakistani plants for milk clotting activity. J. Islam. Acad. Sci. 3(4): 284-286.

13. Dalei, J., V. M. Rao, D. Sahoo, M. Rukmini and R. Ray. 2016. Review on nutritional and pharmacological potencies of moringa oleifera. Eur. J. Pharma. Med. Res. 3(1): 150-155.

14. El-Aziz, M. A., S. H. S. Mohamed and F. L. Seleet. 2012. Production and evaluation of soft cheese fortified with ginger extract as a functional dairy food. Polish J. Food Nutr. Sci. 62:77-83.

15. Fathollahi, I., J. Hesari, S. Azadmard and S. Oustan. 2010. Influence of proteolysis and soluble calcium levels on textural changes in the interior and exterior of Iranian UF white cheese during ripening. World Acad. Sci. Eng. Technol. 66:844-849.

16. Gornall, A.G., C.J. Bardwill and M.M. David.1949. Determination of serum proteins by meals of biuret reagent. J. Biol. Chem. 177: 751-776. 
17. Harun, K.I.I., M.O.M. Abdalla and O.A.O. El Owni. 2015. Chemical composition of Mudaffara cheese manufactured by Solanum dubium coat extract and chymosin. U. K. J. Vet. Med. Anim. Prod. 6(1): 27-37.

18. IDF. 2001. Milk: Determination of nitrogen content (Kjeldahal method). International Dairy Federation Standards, 20-A. Brussels, Belgium.

19. Li, Q., L. Yi, P. Marek and B.L. Iverson. 2013. Commercial proteases: Present and future. FEBS Letters. 587(8): 1155-1163

20. Mahajan, R.T and G.M. Chaudhari. 2014. Plant latex as vegetable source for milk clotting enzymes and their use in cheese preparation. Int. J. Adv. Res. 2(5): 1173-1181.

21. Marshal, R.T. 1992. Standard methods for determination of dairy products. $16^{\text {th }}$ Ed. American Public Health Association. Washington, D.C, USA.

22. Mbikay, M. 2012. Therapeutic Potential of Moringa oleifera Leaves in Chronic Hyperglycemia and Dyslipidemia: A Review. Front. Pharmacol. 3: 24.

23. Meilgaard, M. M., G.V. Civille and T. Carr. 2007. Overall difference tests: Does a sensory difference exist between samples? In: Sensory evaluation techniques (4th edn). CRC Press, New York, USA. pp. 63-104.

24. Mishra, S.P., P. Singh and S. Singh. 2012. Processing of Moringa oleifera leaves for human consumption. Bull. Env. Pharmacol. Life Sci. 2(1): 28- 31.

25. Murtaza, M. A., N. Huma, Z. Hayat, M.S. Murtaza and A. Meraj. 2014. Cheese from cow milk with elevated conjugated linoleic acid levels. J. Fd. Nutr. Res., 2: 506-509.

26. Puglisi, I., G. Petrone and A.R. Lo Piero. 2014. A kiwi juice aqueous solution as coagulant of bovine milk and its potential in Mozzarella cheese manufacture. Food Byproducts Processing. 92 (1): 67-72.

27. Pyrc, K., P. Strzyz, A. Milewska, A. Golda, O. Schildgen and J. Potempa. 2011. Porphyromonas gingivalis enzymes enhance infection with human metapneumo virus in vitro. J. Gen. Virol. 92(3): 2324-2332.

28. Rafiq, S., N. Huma, I. Pasha and M. Shahid. 2016. Compositional Profiling and Proteolytic Activities in Cow and Buffalo Milk Cheddar Cheese. Pak. J. Zool. 48(4): 11411146.

29. Saeed, F., M.U. Arshad, I. Pasha, R. Naz, R. Batool, A. A. Khan, M.A. Nasir and B. Shafique. 2014. Nutritional and phyto-therapeutic potential of Papaya (Carica papaya Linn.): An Overview. Int. J. Food Properties. 17:1637-1653.

30. Saliha, B.H., L.C. Louis, M.M. Farida, S.A. Saliha, M. Nasma, S.O. Elkhir and M. Abderrahmane. 2011. Comparative study of milk clotting activity of crude gastric enzymes extracted from camel's abomasum at different ages and commercial enzymes (rennet and pepsin) on bovine and camel milk. Emir. J. Food Agri. 23(4): 301-310.

31. Shah, M.A., S.A. Mir and M.A. Paray. 2014. Plant proteases as milk-clotting enzymes in cheesemaking: a review. Dairy Sci. Tech. 94(1): 5-16.

32. Silva Junior, G.B., E.M. Santos, R. L. Silva and I.H.L. Cavalcante. 2016. Nutritional status and fruit production of Carica papaya as a function of coated and conventional urea. R. Bras. Eng. Agríc. Ambiental. 20(4): 322-328.

33. Singh, R., M. Kumar, A. Mittal and P.K. Mehta. 2016. Microbial enzymes: industrial progress in 21st century. 3 Biotech. 6(2): 174.

34. Steel, R.G.D., J.H. Torrie and D.A. Dickey. 1997. Principals and Procedures of Statistics. Biometerical Approach. $3^{\text {rd }}$ Ed. McGraw Hill Book Co. Inc., NY, USA.

35. Tejada, L., A. Abellan, F. Prados and J.M. Cayuela. 2008. Compositional characteristics of Murcia al Vino goat's cheese made with calf rennet and plant coagulant. Int. J. Dairy Technol. 61: 119-125.

36. Vyas, S.J, T.T. Khatri, V. R. Ram, P. N. Dave and H.S. Joshi. 2014. Biochemical constituents in leaf of Carica papaya - ethnomedicinal plant of Kachchh region. Int. Lett. Nat. Sci. 12: 16-20.

37. Yogiraj, V., P. K. Goyal, C.S. Chauhan, A. Goyal and B. Vyas. 2014. Carica papaya Linn: An Overview. Int. J. Herbal Med. 2(5): 01-08. 